\title{
Reflexiones hermenéuticas en torno a Peter Cole*
}

\section{Hermeneutics Reflections on Peter Cole}

\author{
Cristina Álvarez de Morales Mercado \\ Facultad de Traducción e Interpretación \\ Universidad de Granada \\ C/ Buensuceso 11. Granada, 18002 \\ cristinaalvarez@ugr.es \\ Orcid ID 0000-0002-8298-8686
}

Resumen: En el presente trabajo ofrecemos unas reflexiones en torno a la figura y la obra de Peter Cole, destacado poeta y traductor de la literatura hebrea y árabe producida en España en torno a los siglos $x$ y Xv. Dichas reflexiones se realizan en el marco de la Cábala y su historia. Más en concreto, nos centraremos en una de las personalidades más destacadas de esta tradición, el poeta Abraham Abulafia, considerado por Peter Cole como el máximo representante de la Cábala más temprana. Abulafia nos servirá de puente para conocer algo más en profundidad la poesía de la Cábala, teniendo en cuenta además que es uno de los poetas por excelencia escogido por Cole en varios de sus trabajos. En este sentido, recogemos en la segunda parte del trabajo una exégesis de cinco poemas seleccionados de la literatura cabalística y analizamos el sentido, el poder y la fuerza de sus versos partiendo de la visión que el propio Peter Cole tiene de ellos.

Palabras clave: Peter Cole. Abulafia. Cábala. Sabatianismo. Judaísmo. Poesía.
RECIBIDO: 19 DE DICIEMBRE DE 2017 ACEPTADO: 7 DE FEBRERO DE 2018

Abstract: In the present paper we offer some considerations on Peter Cole's figure and work. Peter Cole is an important poet and translator of the $\mathrm{He}^{-}$ brew and Arabic poetry produced in Spain around the $10^{\text {th }}$ and $15^{\text {th }}$ centuries. These considerations are developed in the frame of Kabbalah and its History, specifically we will focus on Abraham Abulafia, one of the most essential character in the Kabalistic tradition. Abulafia acts as a kind of bridge to know the poetry of Kabbalah from a detailed point of view. In this sense we collect in the second part of the paper an interpretation of five selected poems from the Kabbalistic tradition and we explore their meaning, power and strength of the verses from own Cole's view.

Keywords: Peter Cole. Abulafia. Sabathianism. Jewish. Poetry.

\footnotetext{
* El artículo que presentamos se enmarca dentro del I+D+i Actualidad de la Hermenéutica. Nuevas tendencias y autores (FFI2013-41662-P), financiado por el Ministerio de Economía y Competitividad para el periodo 2014-2018.
} 


\section{INTRODUCCIÓN}

P

eter Cole es uno de los poetas americanos pertenecientes a la tradición judía más interesante de la actualidad. Alumno aventajado del crítico Harold Bloom, está considerado hoy en día como uno de los traductores más emblemáticos de la poesía hebrea, particularmente de la poesía escrita en España por poetas judíos durante los siglos X y XV. Además del hebreo domina el árabe, por lo que se ha convertido en un autor esencial a la hora de traducir a escritores relevantes de las culturas judía y árabe de los primeros tiempos. El primer trabajo crítico de Cole Things on Which I've Stumbled (2008) y su último trabajo de poesía The Invention of Influence (2014) lo convierten, en palabras de Bloom, en el poeta más vital de todos los de su generación. Ambos libros representan un fenómeno distinto en la literatura americana: la madurez de la esencia y el estilo a través del prisma de las lenguas árabe y hebrea, pero sobre todo a través de su literatura.

Peter Cole nació en Paterson, Nueva Jersey, en 1957. En 1975 empezó sus estudios de Secundaria en el Williams College en Massachusetts. Al año siguiente se traslada a Jerusalén para estudiar hebreo. Vive a caballo entre Nueva York y Jerusalén. Es autor de cinco colecciones de poesía: Rift (1989), Hymns \& Qualms (1998), Things on Which I've Stumbled (2008), What Is Doubled: Poems 1981-1989 (2005) y The Invention of Influence (2014).

Como ya hemos mencionado, Cole es también traductor de gran parte de la literatura hebrea clásica, especialmente de la medieval, ejemplo de ello es su antología The Dream of the Poem (2007), en la que ofrece un bello retrato de la sociedad hebrea del momento a través de los versos producidos por los poetas pertenecientes a las comunidades intelectuales y artísticas judías que florecían en la España cristiano-árabe medieval. Con este trabajo consiguió el National fewish Book Award y también el premio de la Asociación americana de editores. Cole traduce además a muchos poetas judíos contemporáneos, en concreto a reconocidos poetas palestinos, árabes y hebreos tales como Aharon Shabtai, Taha Muhammad Ali y Yoel Hoffmann. Su libro The Poetry of Kabbalab: Mystical Verse from the Jewish Tradition (2012) ganó el premio de traducción Nims Prize. También ha recibido otros premios como el Nacional de las Artes y el Nacional de las Humanidades (Álvarez de Morales 2015a, 1).

En opinión del crítico norteamericano Harold Bloom, Cole ha llegado a ser un destacado escritor de la sabiduría judía, pues ha sido capaz de abrir un recinto alrededor de la escritura secularizada, que comprende a todos los 
autores judíos del exilio imaginativo literario del mayor mérito estético y cognitivo (Cole 2014, x).

\section{Peter Cole, hermeneuta}

En este trabajo nos centraremos en la labor de Cole como hermeneuta y crítico de la poesía hebrea y árabe que se produce en España entre los siglos $\mathrm{X}$ y $\mathrm{XV} .{ }^{1}$ La tarea hermenéutica que lleva a cabo desde los primeros años de este siglo, dio sus mejores frutos en los trabajos The Dream of a Poem y The Poetry of Kabbalah. En estos volúmenes, Cole realiza una exégesis de los distintos estadios de la Cábala y sus autores a lo largo de los siglos y en distintos países: Italia, Francia, España, etc. En opinión de Cole, para la mayoría de los cabalistas, lo judío encarna las propiedades místicas de su lenguaje principal, en el que el Nombre de Dios es el texto y la textura del universo (Cole 2014, 3).

The Dream of the Poem: Hebrew Poetry from Muslim and Christian Spain 950-1492 (2007) está dividido en dos partes. En la primera parte, Cole recupera la voz de algunos poetas que pertenecían a la tradición poética musulmana de la España de los siglos X-XII, tales como Yosef Ibn Avitor, Samuel Hanagid, Josef ibn Hasadai, Salomon Ibn Gabirol, Moses Ibn Ezra, Yehuda Halevi, entre otros. En la segunda parte del libro recopila poemas de los poetas de la España cristiana y la Provenza de los siglos XII-XV, entre los que destacan Abraham ibn Ezra, Yehuda Ibn Sabetai, Yehuda Alharizi, Abraham Abulafia, Todros Abulafia, Josef Giqatilla, Salomo Depiera, Vidal Benveniste, Salomo Halevi, Salomo Bonafed o Moshe Remos. De esta última lista destacamos la figura de Abraham Abulafia, que es el puente que une la tradición cabalística primera con las posteriores, y nos servirá de hilo conductor para entender la simbología de los poemas que hemos seleccionado en la segunda parte del artículo. Cole explica en el prólogo de este libro a qué se debe la selección de este material: "My selection, therefore, reflects canonical preferences, recent findings, and my own tastes, and was made after rereading the entire corpus of the literature" (Cole 2007, XxI), con el principal objetivo de ofrecer al mundo occidental una selecta elección de los poetas que más tuvieron que decir durante esos cinco siglos.

Por otra parte, en The Poetry of Kabbala (2012), Cole se hace eco de la tradición cabalística a través de los poemas más interesantes de cada etapa,

1. Para conocer más sobre la obra de Cole como poeta y traductor, ver Álvarez de Morales 2015a. 
reagrupándolos de la siguiente forma: poemas de los Palacios y los primeros Himnos litúrgicos, poemas del Libro de la Creación, poemas de la Cábala en Al-Andalus y los askenazíes, poemas de la Cábala en España (Abraham Abulafia reaparece aquí de nuevo como uno de los poetas elegidos), poemas del círculo del Safed (o la Cábala de Galilea), poemas de la Cábala del este y del oeste, poemas escritos por los judíos musulmanes y los musulmanes judíos, poemas de la Cábala italiana, los de la devoción hasídica y, por último, los poemas basados en las raíces del misticismo secular. Nos centraremos en este libro en el apartado cinco de este trabajo, cuando analicemos algunos de estos poemas cabalísticos.

Recordemos que la Cábala, que al pie de la letra significa 'tradición' y, en particular, 'tradición esotérica', es el movimiento en el que las tendencias místicas del judaísmo, principalmente entre los siglos XII-XVII, encontraron su sedimentación religiosa en forma de múltiples ramificaciones (Scholem 97). Joan Corominas, en su Diccionario crítico-etimológico castellano e hispánico, documenta esta palabra por primera vez en España entre 1325-1326, como "la interpretación mística del Antiguo Testamento, que pretendía ser tradicional, y posteriormente se aplicó a otras doctrinas esotéricas" (Corominas 708). La Cábala es la tradición entendida como Enseñanza o Sabiduría de lo oculto que fue recibida por Moisés en el Sinaí y transmitida de boca en boca a lo largo de todas las generaciones. Nace de fuentes de conocimiento que no son siempre la razón o la lógica, sino la revelación y la inspiración (Barnatán 17).

La Cábala que estudia Cole a través de los poemas hebreos que traduce no se reduce exclusivamente al pensamiento religioso que empezó a tomar forma a comienzo de los siglos XII y XIII al sur de Francia y España, sino que responde a la manera en la que algunos cabalistas modernos consideran que debe ser entendida la Cábala, como una vuelta a sus raíces, al Talmud, a la propia Escritura, esto es, interpretando la Cábala en su sentido más puramente hebreo, como lo recibido generación tras generación. Además, la tradición espiritual de la Cábala se manifiesta en el trabajo de Cole en la misma línea de Scholem y sus sucesores (Barnatán), es decir, como el regreso de la dimensión mítica hacia la conciencia religiosa. Este es el mapa cabalístico que se perfila en el trabajo místico de Cole, que consistiría en la búsqueda de alegorías de la comprensión, para conseguir al menos una reflexión profunda de la experiencia. La obra de Cole habla sobre la naturaleza de la creación humana y divina, y sobre el lenguaje que dirige dicha creación y se enmarca en el corazón de la Cábala. El gran cabalista Gershom Scholem (52) ya mencionaba la indisoluble unión 
entre la idea de la verdad revelada y la noción del lenguaje, siendo este posiblemente el legado más importante transmitido a la historia de las religiones.

El cabalista, pues, para Cole, se enfrenta al texto poético tomándolo como un conjunto simbólico que habla de realidades místicas y metafísicas, y que debe ser leído distinguiendo en él cuatro sentidos: literario, alegóricofilosófico, hermenéutico y místico. Este aspecto recuerda la teoría de los cuatro sentidos de la escritura en la exégesis cristiana, que defiende que los sentidos ocultos tienen que ser hallados mediante el trabajo de interpretación, pero sin alterar la expresión, es decir, la disposición material del texto, incluso esforzándose por restablecer la lectura exacta.

\section{ABRAHAM ABULAFIA Y EL SIMBOLISMO DE SU POESÍA}

Uno de los poetas favoritos de la tradición cabalística escogido por Cole para reflexionar sobre esta es Abraham Abulafia, de quien habla con frecuencia y al que vuelve reiteradamente para enmarcar sus interpretaciones de los poemas escritos a lo largo de esta tradición. Recordemos que Abraham Abulafia es conocido por ser una de las figuras más importantes de la tradición mística hebrea. En este trabajo nos servirá como eslabón de los cinco poemas que hemos escogido para explicar algunas interpretaciones que Cole hace de varios poemas seleccionados a partir de las diferentes etapas de la Cábala. Para Cole, Abulafia es el cabalista que mejor ha sabido recuperar la esencia de la Cábala al incorporar siempre en sus poemas la imagen de un Dios armonioso, que habla de paz y que se convierte en el rey de reyes, tal y como veremos más adelante en los otros poemas seleccionados de la tradición cabalística.

Abraham Abulafia nació en Zaragoza en 1240, se quedó huérfano con dieciocho años y dos años después comenzó una vida bohemia que le llevó a visitar Palestina, Grecia e Italia, en concreto Sicilia. Su primer viaje fue a tierras de Israel, buscando a las diez tribus perdidas; Abulafia pensaba que encontrándolas ayudaría a propagar la edad mesiánica. En 1271 regresa a Barcelona tras una experiencia mística que le hace creer que posee una inspiración profética, y empieza a enseñar la doctrina cristiana a sus seguidores en España. Pero tres años después regresa a Grecia e Italia. Y en 1280 experimenta otra visión mística, esta vez en las afueras de Roma, donde planeaba encontrarse con el papa Nicolás II para hablarle de la situación de los judíos en el exilio y persuadirlo para que se convirtiera al judaísmo. Esta insinuación casi le cuesta la vida porque el papa lo condena a la horca. Sin embargo, el pontífice muere 
poco después, y el poeta es liberado. Al poco tiempo, acusado de ser un charlatán, la propia comunidad judía lo exilia a la isla de Comino, cerca de Malta. Es allí donde Abulafia escribió su apocalíptico Libro de las letras o de los signos.

Los continuos viajes de Abulafia le hicieron obsesionarse por el complejo mecanismo del lenguaje, insistiendo en la necesidad de la recuperación de los sentidos del texto a través de la numerología y del esoterismo, pues él entendía que era la única forma de comprender el verdadero sentido de los textos y las lenguas de cada lugar al que llegaba. La visión profética que asoma en cada uno de sus poemas implica una síntesis de fuerzas en conflicto donde el proceso interior se externaliza a través de la figuración imaginativa. De hecho, como comenta Idel, en la mayoría de sus poemas del Libro de los signos se manifiesta la lucha entre la facultad imaginativa (representada por la sangre) y la facultad visionaria (representada por la tinta): "And YHVH spoke to me when I saw His Name / spelled out and merged with the Blood in my heart, / separating Blood from Ink and Ink from Blood. / And YHVH said to me: Behold, Blood / is the name of your Soul, and the Ink the name of your Spirit" (en Cole 2012, 113). Parece que Abulafia establecía una distinción entre las 22 letras (y la Torá eterna) como matriz y el hebreo como lengua madre del género humano. De ahí su interés desmedido por comprender el significado de las letras y su simbolismo: "Kingdom now foremost / and the teaching behind, / the teaching foremost / and Kingdom behind: / and the letter, vowels, / and song reveal / the mystery of Blood" (en Cole 2012, 113).

En opinión de Cole, el trabajo de Abraham Abulafia representa un pensamiento único en la tradición cabalística, pues su lenguaje, centrado en el misticismo, utiliza una clase de simbolismo que provenía del Zohar de Castilla y de los círculos de la Cábala más temprana, que se basaban en las sefirots y en la importancia de la cabeza de Dios (Álvarez de Morales 2015b, 209). Abulafia estaba más preocupado por los misterios del presente y del futuro, y sus preocupaciones cabalísticas se centraban sobre todo en la transformación de la mente y del intelecto. Igual que Rimbaud hablaba de la locura sistemática de los sentidos para utilizar los poderes visionarios que se requieren para ser un auténtico poeta, Abulafia insistía en la necesidad de una perturbación sistemática y una reorganización de los sentidos puros del texto a través de lo esotérico y el plano visionario del conocimiento. Esta visión radical, como contrapunto de lectura, disuelve el texto tal y como lo conocemos, desplazando el foco desde la superficie narrativa no solo hacia el campo asociativo de la imagen sino hacia la arquitectura de las palabras individuales y el juego dinámico 
entre las letras, tal y como veremos en los poemas seleccionados que siguen. Este Abulafia nos recuerda a Benjamin cuando habla de

la traducción como un proceso que más que distanciar a uno del punto esencial de un momento lingüístico, lo que hace es meterlo en el corazón, como si la traducción fuese una mudanza de un lenguaje a otro a través de transformaciones continuas, que nada tienen que ver con áreas abstractas de similitud o identidad. (en Cole 2012, 110)

\section{LOS POEMAS CABALÍSTICOS “ELEGIDOS”}

La interpretación de los textos sagrados tenía en la tradición bíblica una larga historia (Lledó 268). Esta tradición es la que Peter Cole nos enseña a través de su labor como traductor y hermeneuta de los poemas que escoge de la misma. En concreto, en el volumen The Poetry of Kabbalab (2012) Cole selecciona un conjunto de poemas muy antiguos recuperados por los descendientes de las familias judías más religiosas después de la destrucción del Segundo Templo en el año 70 a. C. Peter Cole no solo los traduce del hebreo al inglés, sino que además ofrece una breve interpretación del poema que él considera más representativo de cada etapa y que, en cierto sentido, tiene relación con la obra y el estilo de Abulafia. Para Cole (igual que lo eran para Abulafia) los más relevantes son los himnos que hablan del amor a Yavé, el Dios de Israel y celebran la unión con Él: "King of Kings, / God of gods / and Lord of lords" (Cole 2012 , 12). Y por esta razón hemos seleccionado en este trabajo los cinco poemas que siguen, pues el eje central de los mismos es el amor profundo del pueblo judío a su Dios, a Yavé. Otra de las razones por la que hemos seleccionado estos poemas es porque son, además, significativos de una etapa concreta de la Cábala y todos están en la línea del pensamiento de Abulafia: son poemas cargados de un profundo simbolismo. Así pues, el poema "The Priest's Appearance" aparece como poema central de los llamados Poemas de los Palacios, que se corresponden con la tradición de los primeros textos cabalísticos; por su parte el poema "Hymn to the Heavens" es un poema crucial en los Himnos litúrgicos. El poema titulado "Peace be upon You" pertenece a la Cábala de Galilea o del Círculo del Safed; el poema "Meliselda" está recogido entre los poemas más representativos de los escritos musulmanes-judíos y, por último, el poema "I have found Bliss", que es uno de los poemas jasídicos más interesantes, pues el simbolismo de cada imagen que se recoge en sus versos lo convierte en un ejemplo crucial de poema similar a los poemas del Libro de los signos. 
Abordaremos estos cinco poemas a partir de un personal ejercicio hermenéutico basado en los comentarios que Cole hace sobre ellos en este libro.

El primer poema es de "The Priest's Appearance" y pertenece a los llamados Poemas de los Palacios. Lo transcribimos a continuación:

Like an Angel alighted by the edge of the roadwas the priest in appearance;

Like the Bells of gold on the skirts of the robe; was the priest in appearance;

Like the Creatures clothed in the Rock's resplandencewas the priest in appearance;

Like the Descent of grace to the bridegroom's eyeswas the priest in appearance;

Like the Enclosure covered in purple and bluewas the priest in appearance;

Like the Form of the Temple and the curtain of witnesswas the priest in appearance;

Like the Garment of strength that cloaks the purewas the priest in appearance;

Like the Heart of the Rose in the garden of pleasurewas the priest in appearance;

Like the Instant of sunrise seen in the Landwas the priest in appearance;

Like Justice's robe which shields like armorwas the priest in appearance;

Like the King's brow adorned with its Crownwas the priest in appearance;

Like the Lenght of the fringes upon the shawlwas the priest in appearance;

Like the Miter made pure and with pureness wornwas the priest in appearance;

Like the New moon sighted and the blessing begunwas the priest in appearance;

Like the One who waits for a glimpse of the Kingwas the priest in appearance;

Like the Pleiades arrayed aloftwas the priest in appearance;

Like a Question posed to the sages of old- 
was the priest in appearance;

Like the Rainbow's ascent through clouds in the skywas the priest in appearance;

Like the Shine flashing from the heavenly beingswas the priest in appearance;

Like the Tent stretched taut in the heavens' heightswas the priest in appearance;

Like the Urim and Thummin lit with directionwas the priest in appearance;

Like Venus's glow on the eastern horizonwas the priest in appearance;

Like the Windows between which the candles are kindledwas the priest in appearance;

Like the Exultation of the host of heavenwas the priest in appearance;

Like the Young Lily among the thornswas the priest in appearance;

Like Zion aligned with Lord in glorywas the priest in appearance. (en Cole 2012, 20-22)

2. Mi traducción:

La apariencia del sacerdote/ Como un ángel en llamas al borde del camino/ era el sacerdote en apariencia;/ como campanillas de oro en las faldas de su túnica/ era el sacerdote en apariencia;/ como las criaturas vestidas por el resplandor de la roca/ era el sacerdote en apariencia;/ como el descenso de la gracia a los ojos del amante/ era el sacerdote en apariencia;/ como el recinto bañado en añil y azul/ era el sacerdote en apariencia;/ como la forma del templo y la tienda del testimonio/ era el sacerdote en apariencia;/ como la vestimenta de la fuerza que envuelve al puro/ era el sacerdote en apariencia;/ como el corazón de la rosa en el jardín del placer/ era el sacerdote en apariencia;/ como el instante del amanecer visto desde la tierra/ era el sacerdote en apariencia;/ como la toga de la justicia que protege como una armadura/ era el sacerdote en apariencia;/ como la frente del rey adornada con su corona/ era el sacerdote en apariencia;/ como la longitud de los flecos del mantón/ era el sacerdote en apariencia;/ como la mitra hecha pura y recubierta de pureza/ era el sacerdote en apariencia;/ como la luna nueva y la bendición que comienza/ era el sacerdote en apariencia;/ como el que espera la mirada del rey/ era el sacerdote en apariencia;/ como las pléyades conformadas en lo más alto/ era el sacerdote en apariencia;/ como la pregunta hecha a los sabios de la antigüedad/ era el sacerdote en apariencia;/ como el ascenso del arco iris a través de las nubes del cielo/ era el sacerdote en apariencia;/ como el brillo alumbrando desde los seres celestiales/ era el sacerdote en apariencia;/ como la tienda tensada fuertemente en las alturas del cielo/ era el sacerdote en apariencia;/ como el Urim y Tumin encendidos en esta dirección/ era el sacerdote en apariencia;/ como el brillo de Venus en el horizonte oriental/ era el sacerdote en apariencia;/ como las ventanas entre las que se prenden las velas/ era el sacerdote en apariencia;/ como la felicidad de la hueste celestial/ era el sacerdote en apariencia;/ como el tierno lirio entre las espinas/ era el sacerdote en apariencia;/ como Zión alineado con el dios de la gloria/ era el sacerdote en apariencia. 
La imagen central del poema proviene del libro apócrifo de Ben Sira (Eclesiástés), que contiene una descripción muy elaborada del sacerdote Simón ben Yohanan, adiestrado para el servicio del Templo. Este pasaje aparece justo después de la mención a la merkavah o el vehículo de la visión mística, al que siempre se suele asociar con un carro de fuego. En él se habla de las vicisitudes y pruebas psicológicas que tiene que superar el creyente para ascender a los cielos y tener la experiencia mística de unión con Dios: "Like the Creatures clothed in the Rocks' resplandence / was the priest in appearance". La primera parte de este poema recrea la Creación del mundo, su historia, y la historia de Israel antes de su Éxodo en los versos que dicen:

Like the Descent of grace to the bridegroom's eyeswas the priest in appearance;

Like the Enclosure covered in purple and bluewas the priest in appearance;

Like the Form of the Temple and the curtain of witnesswas the priest in appearance;

Like the Garment of strength that cloaks the purewas the priest in appearance;

Like the Heart of the Rose in the garden of pleasurewas the priest in appearance;

La segunda parte describe el ritual de sacrificio practicado en el Templo de Yom Kippur. Si seguimos el acróstico del poema, el sacerdote que aparece como el representante de la santidad de Yom Kippur se une a los elementos de la tradición judía, que son en muchas ocasiones elementos artificiales que encarnan las fuerzas cósmicas en un escenario humano, un tropo que refleja la influencia de la ornamentación propia de estilo bizantino en el que se desarrolla esta tradición: "Like Justice's robe which shields like armor- / was the priest in appearance; / Like the King's brow adorned with its Crown- / was the priest in appearance; / Like the Lenght of the fringes upon the shawl- / was the priest in appearance".

En cuanto a las imágenes de este poema, son tomadas tanto de la tradición bíblica como rabínica y, además, son continuas las alusiones a pasajes del Antiguo Testamento: a Números $(22,22)$ cuando se habla de la Historia de Balaam, en el verso que dice: "Like an Angel alighted by the edge of the road- / was the priest in appearance"; al Éxodo $(28,34)$ con la descripción del sacerdote y las campanillas de oro: "Like the Bells of gold on the skirts of the robe / 
was the priest in appearance"; alusiones al profeta Isaías $(40,22)$ refiriéndose a Dios como el que "expande los cielos como un tul", en el verso que dice: "Like the Tent stretched taut in the heavens' heights- / was the priest in appearance", o a Ezequiel $(1,28)$ que describe el ascenso del arcoíris a través de las nubes: "Like the Rainbow's ascent through clouds in the sky- / was the priest in appearance"; o cuando, por ejemplo, también en Ezequiel $(1,13)$ se habla del fuego que transmite un resplandor del que salen rayos: "Like the Shine flashing from the heavenly beings- / was the priest in appearance". Para Peter Cole, este poema hace referencia en todos sus versos a la Gloria de Dios y como hemos adelantado, alaba a Yavé, el Dios de Israel, celebrando su unión con Dios.

El segundo poema que hemos seleccionado de entre los poemas de los Himnos, es el titulado "Hymn to the Heavens":

You who cancel decrees and unravel vows, remove wrath and bring fury to failure, recalling love and friendship's array before the glory of the Palace of awe:

Why are you now so wholly fearful and now given over to gladness and joy?

Now so strong in your exultation.

And now overcome with terror?

They said: When the wheels of Majesty darken great dread and fear overwhelm usand when the glow of the Presence appears

we soar in tremendous bliss. (en Cole 2012, 6)

En él se empieza mencionando al poeta-místico que se encuentra con los ángeles que ascienden hacia la visión de Dios. Las preguntas que siguen se dirigen a los propios ángeles que tienen que dar cuenta de la naturaleza de la conducta de los otros ángeles y responder cordialmente, convirtiendo este momento en un acto de intimidad y gozo con Yavé: "Why are you now so

3. Mi traducción:

Himno a los cielos/ Tú que cancelas decretos y haces promesas/ aplacas la ira y consigues frenar la violencia/ evocando al amor y al valor de la amistad/ antes de la gloria del Palacio del asombro:/ ¿Por qué tienes a veces ese miedo tan profundo/ y otras te entregas a la alegría y al gozo?/ Tan grande es ahora tu regocijo./ ¿Y, ahora te vence el terror?/ Ellos dijeron: cuando las ruedas de su majestad se oscurecen,/ un gran temor y miedo nos sobrecoge,/ y cuando el resplandor de su presencia aparece/ flotamos en una maravillosa felicidad. 
wholly fearful / and now given over to gladness and joy? / Now so strong in your exultation / and now overcome with terror?".

Los ángeles de los Himnos hablan con un lenguaje vital y profundamente místico, como si asimilaran que "el lenguaje que nos constituye expresa no solo el espacio sociológico, o la cultura en la que nos hemos hecho, sino también los niveles de la propia autobiografía, el espejo siempre deformante de nuestra intimidad" (Lledó 266), y así dicen: "When the wheels of Majesty darken / great dread and fear overwhelm us- / and when the glow of the Presence appears / we soar in tremendous bliss".

Por encima de cualquier interpretación este poema representa la experiencia del contacto con la divinidad como un misterio, reflejando la solemnidad del encuentro con su cadencia en el ritmo y el sonido (Cole 2012, 270). En este sentido, Cole ha respetado el ritmo y los sonidos del original hebreo en su traducción, y ha sabido cuidar las aliteraciones, por ejemplo, del sonido [s] en los versos finales que dicen: "and when the glow of the Presence appears/we soar in tremendous bliss", recuerdan el aleteo de unas alas, ¿las alas de los ángeles?

Recordemos también, tal y como explica Cole en sus comentarios de los poemas de los Himnos, que en ocasiones los ángeles, en la tradición cabalística, son interpretados no solo como pensamientos, sino también como letras, las letras que forman el nombre de Dios. Este poema introduce motivos claves que aparecerán en toda la literatura judía. Incluyen la transcendencia de Dios ante quien los ángeles se postran cantando e intercediendo entre los fieles y la deidad; lo reconocemos en los versos que dicen: "and when the glow of the Presence appears / we soar in tremendous bliss".

Peter Cole nos explica además, cuando comenta este poema, que muchos judíos modernos, en concreto judíos angloparlantes no ortodoxos, se sorprenden al encontrar que los cielos y la historia del judaísmo están plagados de ángeles, buenos y malos, elevados y caídos, ambiguos a veces pero siempre ocupados. Los mensajeros del reino divino (que es lo que significa malakah originalmente) sirven también como cortesanos encargados de la comitiva divina. Son muy comunes en la Biblia y también en el Talmud, la midrash y la liturgia. "Los ángeles quizás son incluso más visibles en la tradición mística judía, donde encontramos ángeles varones y mujeres, agradables y severos, prudentes y corruptos. En ocasiones aparecen como fuego y agua, en otras como los cuatro elementos celestiales: la gracias, la fuerza, la belleza y el reino"4 (Cole 2012,

4. La traducción es mía. 
271). Como ocurre en la Biblia, pueden adoptar forma humana; recordemos que Borges en ocasiones los describía como "fornidos agricultores", pero casi siempre poblaban el reino divino, donde -tal y como deja claro este poemaaparecen siempre cantando y rogando a Dios.

El tercer poema se titula "Peace be upon you" y pertenece a los poemas escritos en torno al Círculo de Safed:

Peace be upon you-

ministering angels, angels of heaven-

from the King who is King of all kings, the Holy One, blessed be He;

in peace be your coming-

angels of peace,

angels of heaven

from the King who is King of all kings,

the Holy One, blessed be He.

Bless me with peace-

angels of peace,

angels of heaven-

from the King of all kings,

the Holy One, blessed be He,

in peace be your leaving-

angels of peace,

angels of heaven,

from the King who is King of all kings,

the Holy One, blessed be He. (en Cole 2012, 136)

Este poema está basado en la tradición talmúdica y nos cuenta que dos ángeles han sido enviados, uno bueno y uno malo, para acompañar a los hombres al hogar de cada uno al inicio del Shabat. El poema alaba el hogar que está preparado para celebrar el Shabat. Así el ángel bueno dice: "será el deseo de

5. Mi traducción:

La paz esté con vosotros/ La paz esté con vosotros,/ ángeles enviados,/ ángeles del cielo,/ del Rey que es el Rey de todos los reyes;/ el más Santo, bendito sea;/ id en paz,/ ángeles de la paz/ ángeles del cielo/ del Rey que es el Rey de todos los reyes/ el más Santo, bendito sea;/ bendecidme con la paz/ Ángeles de la paz/ Ángeles del cielo/ del Rey que es el Rey de todos los reyes;/ el más Santo, bendito sea;/ os marcháis en paz/ángeles de la paz/ ángeles del cielo/ del Rey que es el Rey de todos los reyes/ el más Santo, bendito sea. 
Dios que estemos preparados para el Shabat". Y el otro ángel está obligado a responder "Amén". Pero si la casa no está preparada adecuadamente para el Shabat, la situación se da la vuelta (Cole 2012, 360). Hay interpretaciones anteriores de este poema que defienden que este himno no está dedicado a esos dos ángeles, sino que se le ofrece a un tercero, que aparece transportado entre aromáticas ramas de arrayán que cargan los fieles que vuelven a casa, acompañando esa alma "extra" que los judíos reciben con el Shabat. En realidad el poema puede interpretarse como un himno de la paz del hogar: "Bless me with peace- / angels of peace, / angels of heaven".

Los versos 1-10 están tomados del Salmo 91, 11, que dice: "que Él dará orden sobre ti a sus ángeles, de guardarte en todos sus caminos"; en el poema esta orden aparece en los versos que dicen: "Peace be upon you- / ministering angels, / angels of heaven". También del Salmo 121, 8, que comenta: "Yaveh guarda tus salidas y entradas, desde ahora y por siempre". En el poema del Safed se les dice a los ángeles: "in peace be your coming / angels of peace, / angels of heaven".

Los versos 11-20 los interpreta Cole como señales de gozo cuando los ángeles se marchan, recordemos que en el Deuteronomio $(28,6)$ se nos dice: "Yaveh mandará a la bendición que esté contigo, en tus graneros y en tus empresas, y te bendecirá en la tierra que Yaveh tu Dios te da". En el poema, estas imágenes aparecen en los versos que dicen:

in peace be your leaving-

angels of peace,

angels of heaven,

from the King who is King of all kings,

the Holy One, blessed be $\mathrm{He}$

En opinión de Cole la tradición bíblica, desde Éxodo, Números, Ezequiel, fob o Daniel, por citar algunos, no incluye a los "ángeles enviados" ni a "los ángeles del cielo". De hecho, los lectores de la Biblia del s. XXI no asocian casi nunca la angelología con el judaísmo. Sin embargo, como Cole asegura, los ángeles están sumamente presentes en esta tradición, heredada sobre todo por el judaísmo y sus poetas (Cole 2012, 361). De todos es sabido, sin embargo, que el cristianismo heredó sus ángeles del antiguo judaísmo y de la literatura hebrea midráshica (Álvarez de Morales 1996, 41). Para la tradición cabalística, los ángeles eran emanaciones de la luz divina que hacen el trabajo de Dios en el mundo (Bloom 49). 
El cuarto poema se titula "Meliselda":

I went to the mountain

and down to the river

and there I met Meliselda-

the King's gentle daughter.

I saw that glorious girl

emerging from the water

her brows were bows of night,

her face was a sword of light-

her lips were red as coral,

her milk-like flesh was White. (en Cole 2012, 198) ${ }^{6}$

Aunque con algunas variaciones no demasiado significativas, el poema se encuentra en un buen número de tradiciones europeas, donde la heroína es conocida con diferentes nombres: Melisenda, Belisenda, Bellinsten, Benisela y Belisera, entre otras permutaciones del nombre de la hija de Carlomagno. Entre los judíos otomanos "Meliselda" era el nombre de la "elección". La versión más antigua del poema probablemente se encuentre en la balada francesa del periodo carolingio "Melisenda insomne", aunque sus raíces están en el Cantar de los Cantares (Cole 2012, 404). Peter Cole nos cuenta en The Poetry of Kabbalah que Nathan de Gaza escribe en 1665 al líder de los judíos egipcios y su círculo una extensa carta donde atestigua la capacidad de los himnos y de las canciones para cambiar a los hombres (404). Como decía Scholem (272) "todo debería conseguirse por medio de los himnos".

Moshe Attias (citado en Cole 2012, 404) propone una nueva versión más actual entre las dos versiones que se habían traducido del romancero sefardí. Por su parte, Scholem recuperó la versión del ministro protestante alemán Thomas Coenen, en la que ofrecía su explicación personal de lo ocurrido en la sinagoga. Y esta última es la misma versión que Cole utiliza para interpretar este poema, aunque recupera otras que parece que habían sido cantadas por las comunidades sabatianas, ${ }^{7}$ incluyendo una variación

6. Mi traducción:

Meliselda/ Subí a la montaña/ y bajé al río/ y allí me encontré con Meliselda,/ la gentil hija del Rey./ Vi a esa magnífica criatura/ emergiendo del agua,/ sus cejas eran los arcos de la noche,/ su cara era una espada de luz,/ sus labios eran rojos como el coral/ su piel blanca cual la leche.

7. Recordemos que las ideas místicas de Sabbatai Zevi y sus seguidores eran consideradas para algunos judíos como una postura herética del mesianismo, en el siglo XVII. 
hebrea en la que Melisenda, "the King's gentle daughter", por ejemplo, se convierte en "abogada de Dios", de manera que aparece ante los ojos de la comunidad llena de santidad. Otras variaciones hebreas y ladinas de este tema aparecen también recogidas por algunos poetas modernos como Hayyin Naham Bialik, que traduce el poema siguiendo la pronunciación askenazí.

Lo que los versos del poema encubren es la imagen de santidad que la hija de Carlomagno adquiría para los creyentes sabatianos que la veneraban en todos sus encuentros y la presentaban como "that glorious girl / emerging from the water".

El último poema que presentamos en este trabajo se titula "I have found Bliss" y pertenece a la tradición de los himnos sabatianos. Todos los poemas de esta colección mantienen la rima y el ritmo del original. Peter Cole lo traduce de la versión hebrea de Moshe Attias, que se hallaba en el original ladino de los Himnos sabatianos.

The hour is right

when the light dwells, in darkness

I have found bliss.

And this is the place where life's letter fell, and with that fortune

I have found bliss.

Surely in love and awe I've taken, as our teacher told us:

I have found bliss.

For the soul in its longing

a hint is sufficient-

peace is with him-

I have found bliss.

Mercy is built our faith tells us, and the King renews it.

I have found bliss. 
I've eaten fruit

from the garden-

my soul is sated,

I have found bliss.

Love has come

to terms with Goodness,

in the King's praises

I have found bliss. (en Cole 2012, 199)

En las dos estrofas primeras aparece el verso "the place where tet fell", que nos recuerdan que la letra tet, la novena del alfabeto hebreo, está asociada a la vida y a la vitalidad. Para algunos, es la primera letra de la palabra tov que quiere decir "bueno", como cuando se nos dice en el Génesis: "Y él vio que esto era bueno" (Génesis 1,21). Se asocia también con la novena sefirot, yesod (Fundamento), que a su vez se asocia con la vigorosidad, entendida como el río de la vida. La imagen de la tet cayendo es ambigua y parece aludir al Libro del Zohar cuando decía:

Hay un lugar en la civilización donde ese destructor no tiene poder [...] y todos los que moran allí no morirán hasta que abandonen la ciudad. ¿Por qué es esto así? [...] Cuando el Bendito creó el mundo, lo creó con el misterio de las letras, y las letras, vagando por el mundo, fueron creadas al grabarse con el Nombre Santo [...]. Cuando empezaron a girar y el mundo se estaba expandiendo para ser creado, las letras daban vueltas también para ayudar a crearlo, entonces el Bendito dijo: ¡Es bastante!, se completará con la yod. La letra tet permaneció en ese lugar, suspendida en el aire. Tet es la vida [...] desde que quedó flotando en ese lugar, donde la muerte no tiene potestad. (Cole 2012, 406)

En la tercera estrofa, en concreto el verso que dice: "Our teacher" (nuestro maestro), aparece en el original con la palabra Mor, que suena como moreb y

8. Mi traducción:

He encontrado la felicidad/ La hora es la apropiada/ cuando la luz reside/ en la oscuridad,/ he encontrado la felicidad./ Y este es el lugar/ donde cae la letra de la vida,/ y con esa suerte,/ he encontrado la felicidad./ Seguramente con amor/ y con asombro he conseguido/ lo que nuestro maestro nos dijo:/ he encontrado la felicidad./ Para el alma en su anhelo/ un indicio es suficiente,/ la paz sea con él/ he encontrado la felicidad./ La bondad se construye,/ lo dice nuestra fe,/ y el rey nos lo recuerda,/ he encontrado la felicidad./ He comido la fruta/ del jardín,/ mi alma está sacia$\mathrm{da}, /$ he encontrado la felicidad./ El amor ha asumido/ la bondad/ con los ruegos del Rey,/ he encontrado la felicidad.

9. La traducción es mía. 
que tiene varias acepciones como: el que estira, el arquero, el maestro, lo que es fructífero; de ellas Cole se queda con "maestro". Este mismo nombre nos lleva a varias asociaciones, la primera es con el monte del Myrth, en hebreo mor, que aparece en el Cantar de los Cantares, haciendo referencia a una cadena montañosa en el norte de Israel, ubicada en el lado noreste del Valle de Jezreel. Esta montaña alude al secreto de Abraham que posee la cualidad de $\mathrm{He}$ sed (la Benevolencia) y que está asociada también con los poemas sabáticos y con el Islam, lo que contrasta con la Torah de la Verdad, que es la Ley de Moisés (ver Álvarez de Morales 1996, 41).

Los versos de la cuarta estrofa dicen "Zikhri renews me" en el original, pero en esta versión se dice: "and the King renews it". Según Scholem, Zikbri, literalmente significa "mi recuerdo", pero también "mi rastro". Aquí es el Rey, es Yavé hecho rey de reyes, y el poeta se complace ante su presencia y se siente dichoso, tal y como repite en el estribillo que da título al propio poema "I have found bliss" (Cole 2012, 406-07).

Los versos 25-30 son especialmente oscuros. El poema aquí contiene tres aspectos simbólicos clave del mundo teológico del sabatianismo: El amor (Ahavab) cantado en el verso: "Love has come" parece usarse simbólicamente (como Zikbri) y se mantiene como uno de los tres vínculos (o nudos) de la fe en la trinidad sabatiana. Los otros dos son benevolencia (Zikbri), recogido en el verso que dice: "in the King's praises" y la bondad (Tovah) del verso que dice "to terms with Goodness". Cole los interpreta diciendo que esos tres nudos son también epítetos que se refieren a gente concreta: Tovah se referiría al mayor escritor sabatiano de himnos, Yehuda Levi; la bondad aquí es el símbolo de la Matronita que es como decir, el Sheninab; y la belleza sería el símbolo de la noble señora y mujer de Tiferet (Cole 2012, 407).

\section{CONCLUSIONES}

Como señala Cole y como se ha podido comprobar aquí, los traductores de la poesía cabalística tienen que conocer muy bien todos los elementos de esta tradición: las figuras retóricas, los ecos bíblicos, la naturaleza de las convenciones y la identidad de la obra, la musicalidad del poema, además de sus dimensiones formales, para conseguir un texto ideal en la lengua de llegada. Y, sobre todo, como insiste Cole, tienen que estar familiarizados con la historia de la interpretación en este campo y saber si los poemas se han entendido o no en su propia tradición (Cole 2007, 15). 
Además, Peter Cole defiende una traducción siguiendo la poesía metafísica, es decir, reconstruyendo en cierta medida el idioma de los siglos X, XI y XII. Para otros traductores, traducir esta poesía judía medieval se convierte en una especie de prosa poética, de texto plano, perdiendo en opinión de Cole cualquier efecto poético. Pero el poema tiene un medio físico que debe regularse y manipularse, casi como si se tratase de otra arte más plástica, como si el poema literalmente gritara su presencia física, esto es ni más ni menos, lo que tiene que significar para nosotros; $y$, para conseguirlo, el poeta debe ver en la página escrita y en los estímulos sensoriales del sonido los elementos que anuncian la presencia del poema (Krieger 209).

Así pues, la tarea principal que Cole se propone con su obra es identificar la recreación de la autoridad, saber muy bien cuál es el posible lector y traducir la cultura en definitiva, no solo el texto. Además, aboga por el placer de la lectura del texto, que debe ser el principal foco de intención de todo buen traductor. Para Cole, traducir poesía es mantener el contenido y la forma inseparables: en palabras de Schreiber, el "poeta busca las palabras, las imágenes idóneas, los ritmos convenientes que le digan a él mismo, y también a nosotros, lo que él quiere decir. El poema lo constituyen las palabras" (33). Y esta es la labor de artesanía que Cole realiza en cada poema, en cada palabra que traduce e interpreta del hebreo al inglés, intentando siempre que en las palabras traducidas se respire el alma del poeta que las creó.

La tarea hermenéutica entonces no es únicamente el resultado de un simple proceso de entender mejor y asimilar los restos de la consciencia ajena a través de la escritura, sino que la tarea hermenéutica, como nos enseña Emilio Lledó (265), es una aventura, un riesgo en el que cada personalidad pone en juego los distintos elementos que la integran y, en determinados casos, los intereses que, más o menos conscientemente, la mueven. Interpretar implica situar un lenguaje en el contexto en el que alcanza los límites donde su indecisa semántica parece ajustarse y definirse. Por eso todo lenguaje necesita ser interpretado.

\section{OBRAS CITADAS}

Álvarez de Morales, Cristina. Aproximación a la teoría poética de Harold Bloom. Granada: Universidad de Granada, 1996.

Álvarez de Morales, Cristina. "Peter Cole: poeta, hermeneuta, traductor". Hermeneutic 14 (2015a): 1-12. 
Álvarez de Morales, Cristina. "Harold Bloom: el último cabalista". Tropelías 23 (2015b): 206-22.

Barnatán, Marcos Ricardo. La Kábala. Madrid: Akal, 1986.

Biblia de ferusalén. Bilbao: Desclée De Brouwer, 2009.

Bloom, Harold. El libro de 7. Barcelona: Interzona, 1995.

Cole, Peter. The Dream of the Poem: Hebrew Poetry from Muslim and Christian Spain, 950-1492. Princeton: Princeton UP, 2007.

Cole, Peter. The Poetry of Kabbalab: Mystical Verse from the Fewish Tradition. New York: Yale UP, 2012.

Cole, Peter. The Invention of Influence. London: New Directions, 2014.

Corominas, Joan. Diccionario crítico-etimológico castellano e bispánico. 6 vols. Madrid: Gredos, 1980.

Idel, Moshe. Language, Torah, and Hermeneutics in Abraham Abulafia. New York: New York UP, 1988.

Krieger, Murray. Theory of Criticism: A Tradition and Its System. Baltimore/ London: John Hopkins UP, 1976.

Lledó, Emilio. Imágenes y palabras. Madrid: Taurus, 1998. 259-81.

Scholem, Gershom. La cábala y su simbolismo. Madrid: Akal, 1988.

Schreiber, S. M. Introducción a la crítica literaria. Barcelona: Labor, 1971. 